\title{
1I Macrothink
}

\section{Effect of Supplier and Customer Collaboration on Product Innovativeness: A Focus on Small and Medium-Sized Enterprises (SMES) in Kenya}

\author{
Patrick Gudda \\ Maasai Mara University, School of Business \& Economics; Business Management \\ Department \\ P. O. Box 861-Narok, Kenya. \\ Corresponding Author: Tel: +254-723559912/ 733-699241 E-mail: pgudda9@gmail.com

\section{Henry M. Bwisa} \\ Jomo Kenyatta University of Agriculture \& Technology P. O. Box 62000- 00200, Nairobi, \\ Kenya School for Human Resource Development Entrepreneurship and Procurement \\ Department \\ Phone: +254-722-858507 E-mail: bwihem@gmail.com \\ John M. Kihoro \\ Jomo Kenyatta University of Agriculture and Technology P. O. Box 62000-00200, Nairobi, \\ Kenya Faculty of Science; Statistics and Actuarial Science Department Phone: \\ +254-715-973820 E-mail: kihoro_jm@yahoo.com, kjm@fsc.jkuat.ac.ke \\ Doi:10.5296/ijld.v3i5.4525ＵRL: http://dx.doi.org/10.5296/ijld.v3i5.4525
}

\begin{abstract}
This study investigated the effect of supplier and customers' collaboration on product innovativeness in manufacturing SMEs. Using a cross sectional survey design with a sample size of 196, a standard multiple linear regression (MLR) was performed between product innovativeness as the dependent variable and the dimensions of supplier and customer collaboration, as independent variables. The results of the supplier collaboration regression indicated that the predictors explained $45.1 \%$ of the variance $\left(R^{2}=.477\right.$, Adj $\left.R^{2}=.451\right), F(6$, $119)=18.115, \mathrm{p}<.001 ; \mathrm{t}=1.995$.; that of customer collaboration indicated that the predictors explained $38.8 \%$ of the variance $\left(\mathrm{R}^{2}=.388\right.$, Adj $\left.\mathrm{R}^{2}=.358\right), \mathrm{F}(6,119)=12.597, \mathrm{p}<.001$; $\mathrm{t}=6.441$. Understanding customer needs is the only dimension that significantly contributed positively to predicting PI $(\mathrm{B}=1.169, p=.056) \mathrm{t}=1.930$. It is concluded that supplier dimensions of win-win relationships, deep suppliers trust, expertise from suppliers and support in product launch will positively predict PI. Similarly, customer collaboration dimension of deep understanding of customer needs will positively predict PI. The researchers recommend the setting up of SMEs support policies that promote collaborations in research for purposes of sharing information / accessing the diverse knowledge base on new product design, development and production.
\end{abstract}

Keywords : Small and medium-sized enterprises, Manufacturing, Collaboration, Product Innovativeness, Kenya

\subsection{Introduction}

Innovation is not a firm internal matter but is increasingly generated in collaboration with external firms. Suppliers and customers may provide a valuable contribution to new product 
development (NPD) as they provide access to external knowledge that complements the firm's internal knowledge base. This external knowledge is important as innovation is considered the result of a recombination of elements from different knowledge bases (Henderson \& Clark, 1990; Kogut \& Zander, 1992), which usually do not reside within a single firm. Research in the field of supplier and customers' collaboration in NPD is quite extensive. Existing studies provide valuable insight into antecedents, motives, success factors etc. for supplier collaboration in NPD (Johnsen, 2009). However, the actual contributions of suppliers to innovation are underexposed. This paper focuses specifically on what knowledge suppliers and customers contribute to innovation. Several studies have found that supplier and customers collaboration is positively related to product innovativeness. However, many studies do not explicitly describe when and whether suppliers and customers actually are the brains behind the innovation, if they contribute with new technologies, if they are used as sparing partners, or if suppliers and customers contribute in another way to innovation.

The purpose of this paper is to provide an overview of existing research, analyse what existing studies reveal about the contributions of suppliers and customers to innovation, and develop a model categorizing supplier and customers inputs to innovation and the conditions for knowledge integration. This paper is organized as follows; first the theoretical perspective, continued by an explanation of the method and research approach. Then the literature overview provides an overview of the contributions made in the field of supplier and customer's collaboration in product innovativeness, followed by the results of data analysis. It is discussed to what extent the literature provides sufficient answers to what suppliers actually contribute to innovation and a framework for analyzing different contributions is formulated.

\section{Literature Review and Hypotheses}

\subsection{Product Innovativeness (PI)}

Ali, Krapfel and LaBahn (1995) defined product innovativeness as the uniqueness or novelty of a new product to the customer. According to Van de Ven (1986) product innovation refers to the development and implementation of a new product in the adopting firm or markets. Similar to Rogers' (2003) innovation characteristics of a new product (relative advantage, compatibility, complexity, observability, and trialability), product innovativeness refers to the radicalness, uniqueness, and meaningfulness of a new product. Based on the review of existing literature, this study operationalizes product innovativeness as the propensity of a firm to innovate or develop new products that meet and / or exceed customers' expectations or the extent of unmet market needs as reflected in its uniqueness in comparison to similar products offered in the market.

\subsection{Theory and Hypothesis Development: Customer / Supplier Collaboration and Product Innovativeness}

\subsubsection{Customer Collaboration}

SMEs consider their customers and competitors as their biggest resource. Close customer proximity and hence detailed knowledge of individual customer (customer-orientation) accounts can lead to innovation in products that are primarily customer driven (Voss, 1998). According to Renko, Carsrud and Brännback (2009) customers can first, provide major inputs that improve the quality of innovation. Second, close partnerships with customers during product development may provide access to resources that the focal firm lacks in-house. Tang and Murphy (2012) posit that Knowledge of specific customer problems involves knowing 


\section{1) Macrothink}

what customers would prefer instead of other alternatives; in turn such knowledge is instrumental in developing new products in which potential customers will respond positively. Thus, customer proximity may lead to an advantage in terms of product innovation ( $\mathrm{Li} \&$ Calantone, 1998; Tsai, 2009) based on customer needs and wants.

Hypothesis 1: Collaboration with Customers is positively related with product innovativeness.

\subsubsection{Supplier Collaboration}

Mytelka (2002) avers that proximity facilitates informal knowledge flows that stimulate innovation in clusters. Proximity allows firms to interact face to face which in turn builds trust and a common process for exchanging ideas (Lan \& Zhangliu, 2012; Pavlovich \& Akoorie; 2005). The collaboration with other firms and the direct contact with customers reduce risks and durations of the innovation process because of direct or informal information transfer between partners, firms and their clients or between firms and research institutions (Boja, 2011). Close contacts with suppliers may help a firm acquire quality materials, good services, benefit from a supplier's know-how and achieve timely delivery. Similar ties with buyers may spur customer loyalty, sales volume, and reliable payment. According to RBV, these different types of ties may be regarded as valuable, unique, and intangible resources that are difficult to imitate, thus giving firms possessing such ties a significant advantage in developing innovative products.

Hypothesis 2: Collaboration with Suppliers is positively related with product innovativeness.

\section{Research Methodology}

\subsection{Design and data collection}

This study adopted a cross-sectional survey design, to provide a numeric description of the fraction of the population - the sample -through data collection process, using a questionnaire and observation guide at one point in time, with the findings being generalized to a population (Creswell, 2009).

\subsection{Population and Sample}

The focus of this study is at the firm level with the unit of analysis being the manufacturing SME. The sampling frame were all manufacturing SMEs registered and licensed within Kisumu town as contained in the Official Registry of SME Associations of Kisumu, (2011), The sample size was determined according to Krejcie and Morgan (1970) survey table of samples that recommend a sample size of 196 for a population 342, at $95 \%$ confidence with $5.0 \%$ margin of error. Purposive sampling was then used to select the 136 respondent owner-managers.

\subsection{Data Analysis}

Of all the 142 questionnaires returned, only 126 were found usable and included in the analysis. Descriptive analysis means, and multiple regression analyses were conducted to examine the various aspects and relationship s among variables. In the current study, the dimensions of supplier and customer collaboration measures were the predictor variables and the product innovativeness measure was the criterion variables. 


\section{Results}

\subsection{Hypotheses Testing}

Variance inflation factor (VIF) was used to examine multicollinearity with no value going beyond the critical level of 5 and none of the tolerance approached zero, implying no multicollinearity problem (Hair et al., 2010). The results are shown in Table 1 and 2.

Table 1: Regression coefficients Results of Customer Collaboration on Product Innovativeness

\begin{tabular}{|c|c|c|c|c|c|c|c|}
\hline Variables & B & S.E. & $\beta$ & $\mathrm{t}$ & $P$ & Tolerance & VIF \\
\hline (Constant) & 8.670 & 1.346 & & 6.441 & .000 & & \\
\hline Value customer input & .673 & .635 & .161 & 1.060 & .291 & .224 & 4.464 \\
\hline $\begin{array}{l}\text { Understand customer } \\
\text { needs }\end{array}$ & 1.169 & .606 & .289 & 1.930 & .056 & .229 & 4.369 \\
\hline Customer involvement & .562 & .599 & .131 & .938 & .350 & .264 & 3.790 \\
\hline $\begin{array}{l}\text { Customer familiarity with } \\
\text { new product }\end{array}$ & .154 & .552 & .037 & .279 & .781 & .298 & 3.357 \\
\hline Keep promises & -.147 & .502 & -.036 & -.294 & .770 & .350 & 2.857 \\
\hline $\begin{array}{l}\text { Utilize customer expertise } \\
\text { in product }\end{array}$ & .448 & .351 & .119 & 1.275 & .205 & .587 & 1.703 \\
\hline
\end{tabular}

$\mathrm{R}=.623 ; \mathrm{R}^{2}=.388 ; \mathrm{R}^{2} \mathrm{adj}=.358 ; \quad p \leq 0.05$

The results of the regression indicated the predictors explained $38.8 \%$ of the variance $\left(\mathrm{R}^{2}=\right.$ .388 , Adj $\left.\mathrm{R}^{2}=.358\right), \mathrm{F}(6,119)=12.597, \mathrm{p}<.001 ; \mathrm{t}=6.441$. The results show no significant predictor of customer collaboration on PI except for the unique significant contribution of understanding customer needs that positively predicted PI $(\mathbf{B}=1.169, p=.056) \mathrm{t}=1.930$. The findings imply that taking all other independent variables at zero, a unit increase in understanding customer needs will lead to a 1.169 increase in PI. Taken together, Hypothec 1 was rejected.

Based on the summary of multiple regression analysis results as presented in the table above, accordingly, the equation of multiple linear regressions could be formulated as follows:

$$
\mathrm{Y}=8.670+.673 \mathrm{X}_{1}+1.169 \mathrm{X}_{2}+.562 \mathrm{X}_{3}+.154 \mathrm{X}_{4}-.147 \mathrm{X}_{5}+.448 \mathrm{X}_{6}
$$

Table 2: Regression coefficients Results of Supplier Collaboration on Product

\section{Innovativeness}

\begin{tabular}{|c|c|c|c|c|c|c|c|}
\hline Variables & B & S.E. & $\boldsymbol{\beta}$ & $\mathrm{t}$ & $p$ & Tolerance & VIF \\
\hline (Constant) & 4.750 & 2.380 & & 1.995 & .048 & & \\
\hline Win-win relationships & 2.089 & .450 & .464 & 4.644 & .000 & .440 & 2.273 \\
\hline $\begin{array}{l}\text { Obtain Market } \\
\text { information }\end{array}$ & .363 & .480 & .075 & .756 & .451 & .449 & 2.228 \\
\hline Deeply Trust suppliers & .898 & .380 & .204 & 2.363 & .020 & .590 & 1.695 \\
\hline Expertise from suppliers & .767 & .365 & .171 & 2.101 & .038 & .660 & 1.515 \\
\hline $\begin{array}{l}\text { support in conducting } \\
\text { research }\end{array}$ & -.433 & .330 & -.101 & -1.313 & .192 & .737 & 1.356 \\
\hline support in product launch & .717 & .292 & .166 & 2.452 & .016 & .961 & 1.041 \\
\hline
\end{tabular}


$\mathrm{R}=.691 ; \mathrm{R}^{2}=.477 ; \mathrm{R}^{2} \mathrm{adj}=.451 ; \quad p \leq 0.05$

The results of the regression indicated the predictors explained $45.1 \%$ of the variance $\left(\mathrm{R}^{2}=.477\right.$, Adj $\left.\mathrm{R}^{2}=.451\right), \mathrm{F}(6,119)=18.115, \mathrm{p}<.001 ; \mathrm{t}=1.995$. Four predictors exhibited significant positive effects on PI: acquiring win-win relationships $(\mathrm{B}=2.089, p<.001) \mathrm{t}=4.644$; deeply trust suppliers $(\mathrm{B}=.898, p=.020) \mathrm{t}=2.363$; expertise from suppliers $(\mathrm{B}=.767, p=.038)$ $\mathrm{t}=2.101$ and support in product launch $(\mathrm{B}=.717, p=.016) \mathrm{t}=2.452$. Two predictors had insignificant and positive effects on PI: obtain market information $(\mathrm{B}=.363, p=.451) \mathrm{t}=.756$; support in conducting research was negative $(\mathrm{B}=-.433, p=.192) \mathrm{t}=-1.313$. The findings imply that taking all other independent variables at zero, a unit increase in win-win relationships will lead to a 2.089 increase in PI; a unit increase in deep suppliers trust will lead to a .898 increase in PI; a unit increase in expertise from suppliers will lead to a .767 increase in PI ; a unit increase in support in product launch will lead to a .717 increase in PI Taken together, hypothesis 2 was supported.

Based on the summary of multiple regression analysis results as presented in the table above, accordingly, the equation of multiple linear regressions could be formulated as follows:

$$
\mathrm{Y}=4.750+2.089 \mathrm{X}_{1}+.363 \mathrm{X}_{2}+.898 \mathrm{X}_{3}+.767 \mathrm{X}_{4}-.433 \mathrm{X}_{5}+.717 \mathrm{X}_{6}
$$

\section{Discussion}

For hypothesis 1 , this study found an insignificant effect of customer collaboration on PI, rejecting Hypothec 1. This finding is in contrast to the studies of Grinstein (2008) and Laforet (2008) who found a positive link between customer orientation and innovativeness. Nonetheless, one dimension of customer collaboration, understanding customer needs, was found to significantly predict PI $(\mathbf{B}=-.746, p=.056) \mathrm{t}=1.930$. According to Dibrell, Craig and Hansen, (2011) customers are the information nerve centres of competition, as they not only provide benefits in identifying market opportunities, but also reduce the likelihood of poor design in the early stages of product development). Thus, understanding customer needs may lead to an advantage in terms of product innovation (Li \& Calantone, 1998; Tsai, 2009) by creating a deep knowledge base about customer desires and wants, emerging market trends, and also sharpens the firm's ability to add new value.

Hypothesis 2 assessed the effect of supplier collaboration on PI. The findings showed that supplier collaboration has a significant positive effect on PI. Boja, (2011) avers that the collaboration and proximity to other firms and the direct contact with entrepreneurs in the same field reduces risks and durations of the innovation process because of direct or informal information transfer between partners, firms and their clients or between firms and research institutions. (Isobe, Makino, \& Montgomery, 2008). According to RBV, these different types of ties are regarded as valuable, unique, and intangible resources that are difficult to imitate, thus giving firms possessing such ties a significant advantage in manufacturing innovative products.

\subsection{Conclusion}

This study investigated effect of customer and supplier collaboration on product innovativeness of manufacturing MSEs in Kisumu Town with a view to generating appropriate mix of collaboration strategies for the improvement of their product innovativeness. This was in relation to MSEs lack of continual improvement and enhancement of their product 
innovativeness. The study established that supplier and not customer collaboration significantly predict PI.

\subsection{Recommendations}

The researcher recommends the setting up of MSEs support policies that promote collaborations in research for purposes of sharing information / accessing the diverse knowledge base on new product design, development and production. Such collaborations and the direct contact with customers will reduce risks and durations of the innovation process because of direct or informal information transfer between partner firms and research institutions, hence enhanced product innovativeness.

\subsection{Areas for Further Research}

Researchers should replicate this study across multiple industries and sectors using a larger sample. This would increase our understanding of MSE collaboration concept. The study did not investigate firm-specific collaboration activities that may influence firm ability to translate information into innovative products. Therefore, this is a line of investigation that future research should embrace.

\section{Acknowledgement}

\section{References}

Ali, A., Krapfel, R. Jr., \& Labahn, D. (1995). "Product innovativeness and entry strategy: impact on cycle time and break-even time."Journal of Product Innovation Management. $12(1), 54-70$.

Boja, C. (2011). "Clusters Models, Factors and Characteristics." International Journal of Economic Practices and Theories. Vol. 1, No. 1, 2011 (July) pp 34-43

Creswell, J. W. (2009). Research design: Qualitative, quantitative and mixed methods approach (3rd ed.).

Dibrell, C., Craig, J. \& Hansen, E. (2011). "Natural Environment, Market Orientation, and Firm Innovativeness: An Organizational Life Cycle Perspective." Journal of Small Business Management 49(3), pp. 467-489

Grinstein, A. (2008). "The Effect of Market Orientation and Its Components on Innovation Consequences: A Meta-Analysis." Journal of the Academy of Marketing Science 36, $166-173$.

Hair, J. F., Black, W., Babin, B., Anderson, R. E., \& Tatham, R. L. (2010). Multivariate data analysis: a global perspective, Upper Saddle River, N.J.: Pearson.

Henderson, R.M. and Clark, K.B. (1990) 'Architectural Innovation - the Reconfiguration of Existing Product Technologies and the Failure of Established Firms', Administrative Science Quarterly, Vol.35, No.1, pp. 9-30.

Kogut, B. \& Zander, U. (1992) 'Knowledge of the Firm, Combinative Capabilities, and the Replication of Technology', Organization Science, Vol.3, No.3, pp. 383-397.

Krejcie, R.V. \& Morgan, D.W. (1970). "Determining sample size for research activities." Educational and Psychological Measurement. Available at http://research-advisors.com, pdf. Vol 30: 607-610. Retrieved on 10/11/12.

Lau, A.K.W., Tang, E. \& Yam, R.C.M. (2010). "Effects of Supplier and Customer Integration on Product Innovation and Performance: Empirical Evidence in Hong Kong 
Manufacturers." Journal of Product Innovation Management, Vol. 27, No. 5, pp. $761-777$

Laforet, S. (2008). "Size, Strategic, and Market Orientation Affects on Innovation." Journal of Business Research.61, 753-764.

Lan, W. \& Zhangliu, W. (2012). "Research on Interactive Learning, Knowledge Sharing and Collective Innovation in SMEs Cluster." International Journal of Innovation, Management and Technology. 3(1) February 2012 pp 24-29. pdf. Retrieved on 12/04/12.

Pavlovich, K. \& Akoorie, M. (2005). "Cluster analysis: Mapping the Nelson seafood industry." The University of Auckland: Business review. 7 (2) pp 55-63 pdf. Retried 13/04/12

Renko, M., Carsrud, A. \& Brännback, M. (2009). "The Effect of a Market Orientation, Entrepreneurial Orientation and Technological Capability on Innovativeness: A Study of Young Biotechnology Ventures in the United States and in Scandinavia." Journal of Small Business Management. 47(3), pp. 331-369

Rogers E.M. (1995). Diffusion of Innovations (4th edn). Free Press: New York.

Tang, J. \& Murphy, P. J. (2012). "Prior Knowledge and New Product and Service Introductions by Entrepreneurial Firms: The Mediating Role of Technological Innovation". Journal of Small Business Management 50(1), pp. 41-62

Tsai, K.H. (2009), "Collaborative network and product innovation performance." Research Policy.38 (5) pp. 765-78. 